\title{
Removal of Metallic Impurities from Off-Grade Copper Concentrate in Alkaline Solution
}

\author{
Zhi-xiong Liu1,2,3*, Lin Sun ${ }^{1,2}$, Liang-dong Tang1,2, Jie Hu1,2, Yang Xiao ${ }^{1,2}$, \\ Yi-guang Chen ${ }^{4}$, Zhou-lan Yin ${ }^{5}$
}

${ }^{1}$ College of Physics and Mechanical \& Electrical Engineering, Jishou University, Jishou, China

${ }^{2}$ The Collaborative Innovation Center of Manganese-Zinc-Vanadium Industrial Technology (the 2011 Plan of Hunan Province), Jishou University, Jishou, China

${ }^{3}$ Key Laboratory of Mineral Cleaner Production and Exploit of Green Functional Materials in Hunan Province, Jishou University, Jishou, China

${ }^{4}$ College of Biology and Environmental Sciences, Jishou University, Jishou, China

${ }^{5}$ School of Chemistry and Chemical Engineering, Central South University, Changsha, China

Email: *liuzhxi@sina.com

How to cite this paper: Liu, Z.-X., Sun, L., Tang, L.-D., Hu, J., Xiao, Y., Chen, Y.-G. and Yin, Z.-L. (2018) Removal of Metallic Impurities from Off-Grade Copper Concentrate in Alkaline Solution. International Journal of Nonferrous Metallurgy, 7, 9-23. https://doi.org/10.4236/ijnm.2018.72002

Received: January 28, 2018

Accepted: April 25, 2018

Published: April 28, 2018

Copyright $\odot 2018$ by authors and Scientific Research Publishing Inc. This work is licensed under the Creative Commons Attribution International License (CC BY 4.0).

http://creativecommons.org/licenses/by/4.0/

c) (i) Open Access

\begin{abstract}
The removal of metallic impurities from off-grade copper concentrate was investigated in alkaline solution with $\mathrm{H}_{2} \mathrm{O}_{2}$. The analysis results of XRD and SEM-EDS revealed the oxidative mechanisms of all sulfides. The influence of various parameters of alkaline leaching were investigated including concentrations of sodium hydroxide and hydrogen peroxide, liquid to solid ratio, leaching time and temperature. The results showed that the removal rate of Mo, As and $\mathrm{Zn}$ were increased with increasing leaching time and $\mathrm{H}_{2} \mathrm{O}_{2}$ concentration, and that the removal rate of $\mathrm{Mo}$, As and $\mathrm{Zn}$ were firstly increased and then slightly decreased with increasing liquid to solid ratio, temperature and $\mathrm{NaOH}$ concentration, respectively. More than $95 \% \mathrm{Mo}$, $94 \%$ As, and $94 \%$ $\mathrm{Zn}$ are removed from the off-grade concentrate under the optimum conditions, while only $1.7 \% \mathrm{Cu}$ is dissolved. These optimum conditions were sodium hydroxide $1.5 \mathrm{~mol} / \mathrm{L}$, hydrogen peroxide $1.0 \mathrm{~mol} / \mathrm{L}$, temperature $50^{\circ} \mathrm{C}$, liquid to solid ratio $5 / 1 \mathrm{~mL} / \mathrm{g}$ and leaching time $5 \mathrm{~h}$.
\end{abstract}

\section{Keywords}

Copper Concentrate, Impurities, Removal, Alkaline Leaching, Hydrogen Peroxide

\section{Introduction}

In China, There are many porphyry copper deposits bearing molybdenum, ar- 
senic, zinc and aluminum et al. [1]-[7]. The copper concentrate is often obtained by conventional flotation process, but those impurities of molybdenum, arsenic, zinc and aluminum usually exist in copper concentrates. Molybdenum, aluminum and zinc are valuable metals worthy of being recovered, but arsenic lowers the economic value of the copper concentrate when the presence content of arsenic is higher than $0.5 \%$ in copper concentrate [8].

The copper concentrates with the content of arsenic less than $0.5 \%$ are generally processed by smelting/converting technology. Whilst the copper concentrates contain high amount of arsenic, the smelting/converting technology has a potential risk of environmental pollution with toxic arsenic compounds. In addition, the presence of arsenic in copper concentrates will result in the deterioration of the quality of the final copper cathodes.

There are an off-grade copper concentrate with high content of arsenic (2.17\%) and low content molybdenum (2.62\%), which is collected from Tibet region in China. Owing to high content of arsenic and low content of molybdenum, this copper concentrate is low economic value and is difficult to sell out. Therefore the removal impurities from this off-grade concentrate make a focus.

The removal methods of arsenic such as alkaline leaching and acid leaching have been investigated from copper concentrate, for example, enargite leaching with $\mathrm{Na}_{2} \mathrm{~S}-\mathrm{NaOH}, \mathrm{NaHS}-\mathrm{NaOH}$ and $\mathrm{NaOH}-\mathrm{H}_{2} \mathrm{O}_{2}$ media [9] [10] [11], tennantite and enargite oxidation leaching with $\mathrm{H}_{2} \mathrm{O}_{2}$ at $\mathrm{pH} 5.0$ [12] and enargite leaching using atmospheric in acidic ferric sulfate media [13]. Likewise, the separation of molybdenum from sulfide ores by wet leaching has been studied including the oxygen pressure [14], sodium hypochloride [15], electro-oxidation [16] and bioleaching methods have been performed [17].

Although there many reports on dealing with molybdenite and As-sulfides, respectively, there is little information concerning the treatment of copper concentrate associated with arsenic, molybdenum and zinc. To upgrade the copper concentrate, a new method is investigated to remove the impurities in the copper concentrate in alkaline solution using $\mathrm{H}_{2} \mathrm{O}_{2}$ as an oxidant.

\section{Materials and Experiments}

\subsection{Copper Concentrate and Reagents}

An off-grade copper concentrate with chalcopyrite, tennantite and molybdenum was selected as the raw material in this work to better understand the leaching behavior of metals in the alkaline leaching process. The concentrate was from Huatailong Mining Development Co. Ltd, Mozhugongka region in Tibet province, P.R. China. It was first dried overnight in an oven to remove moisture, and then sieve to collect particles of less than $0.075 \mathrm{~mm}$. All chemicals like sodium hydroxide and hydrogen peroxide were of analytical grade, supplied by Shanghai Sinopharm Chemical Co. Ltd, Republic of China.

\subsection{Leaching Tests}

All leaching experiments were conducted in a conical flask using a shaking ma- 
chine. The copper concentrate sample was used in 20 to $100 \mathrm{~g}$ scale. The liquid to solid ratio varied from $2 / 1$ to $10 / 1 \mathrm{~mL} / \mathrm{g}$. The temperature variation studies were performed from $20^{\circ} \mathrm{C}$ to elevated temperature $70^{\circ} \mathrm{C}$. The concentrations of $\mathrm{NaOH}$ and $\mathrm{H}_{2} \mathrm{O}_{2}$ were changed from 0.5 to $2.5 \mathrm{~mol} / \mathrm{L}$ and 0.4 to $1.4 \mathrm{~mol} / \mathrm{L}$, respectively. The leaching time also was ranged from $1 \mathrm{~h}$ to $7 \mathrm{~h}$. After a certain leaching treatment, the slurry was withdrawn from the reactor and vacuum filtered was washed twice with $400 \mathrm{~mL}$ distilled water. The volume of the filtered pregnant solution was measured by a measuring cylinder and $5 \mathrm{~mL}$ of liquor sample was collected to assay molybdenum, copper, arsenic and zinc by an inductive coupled plasma-atomic emission spectrometer (ICP-AES), and then the residues were dried for $8 \mathrm{~h}$ at $105^{\circ} \mathrm{C}$. The dried residues were used to be analyzed.

\subsection{Analysis and Methods}

$\mathrm{S}$ content in solid samples was determined using a high frequency IR carbon and sulfur analyzer (CS-3000, Beijing Nake Analysis Instrument Co. Ltd). The other elements in solid samples were all analyzed using acid or alkaline digestion and atomic absorption spectrometer (PE-AA700, PerkinElmer Company, USA). Element concentrations in solution were all measured by an inductive coupled plasma-atomic emission spectrometer (Optima 2100DV, PerkinElmer Company, USA). Mineral compositions of solid samples were performed by an X-ray diffractometer (D/Max 2500, Rigaku). The constituents and morphology of the copper concentrates before and after leaching were examined by Scanning Electron Microscope-Energy Dispersive X-Ray spectroscopy analyses (SEM-EDS, Jeol JSM 6010LA) at 10-20 KeV and high vacuum conditions.

\section{Results and Discussion}

\subsection{Analyses and Characterization}

Table 1 shows in the chemical composition of a copper concentrate sample, indicating that besides copper and iron, silicon, sulfur, arsenic, calcium and zinc are the main associated with elements. Mineralogical analysis of the copper concentrate given in Figure 1 indicates the sample consists of chalcopyrite $\left(\mathrm{CuFeS}_{2}\right)$, tennantite $\left(\mathrm{Cu}_{12} \mathrm{As}_{4} \mathrm{~S}_{13}\right)$, molybdenite $\left(\mathrm{MoS}_{2}\right)$, calcite $\left(\mathrm{CaCO}_{3}\right)$ and quartz $\left(\mathrm{SiO}_{2}\right)$. The phase of zinc exists as zinc sulfide by chemical phase analysis [18].

\subsection{Theoretical Leaching Behaviors of $\mathrm{Cu}, \mathrm{As}$, Mo and $\mathrm{Zn}$ Phase and Chemistry of Solution}

The removal of metallic impurities from the copper concentrate is related to the oxidation and dissolution of sulfides including $\mathrm{Cu}-$, As-, Mo- and $\mathrm{Zn}$ - sulfides in the copper concentrate. The leaching behaviors of metal phases in the copper concentrate under alkaline leaching conditions can be predicted from thermodynamic diagrams.

Figure 2 indicates the thermodynamically stable regions of the form of $\mathrm{Cu}, \mathrm{Fe}$ and sulfur in aqueous solution. In the $\mathrm{Cu}-\mathrm{Fe}-\mathrm{S}-\mathrm{H}_{2} \mathrm{O}$ system [19], soluble $\mathrm{Cu}^{2+}$, 
Table 1. Chemicalcomposition of copper concentrate sample (\%,wt).

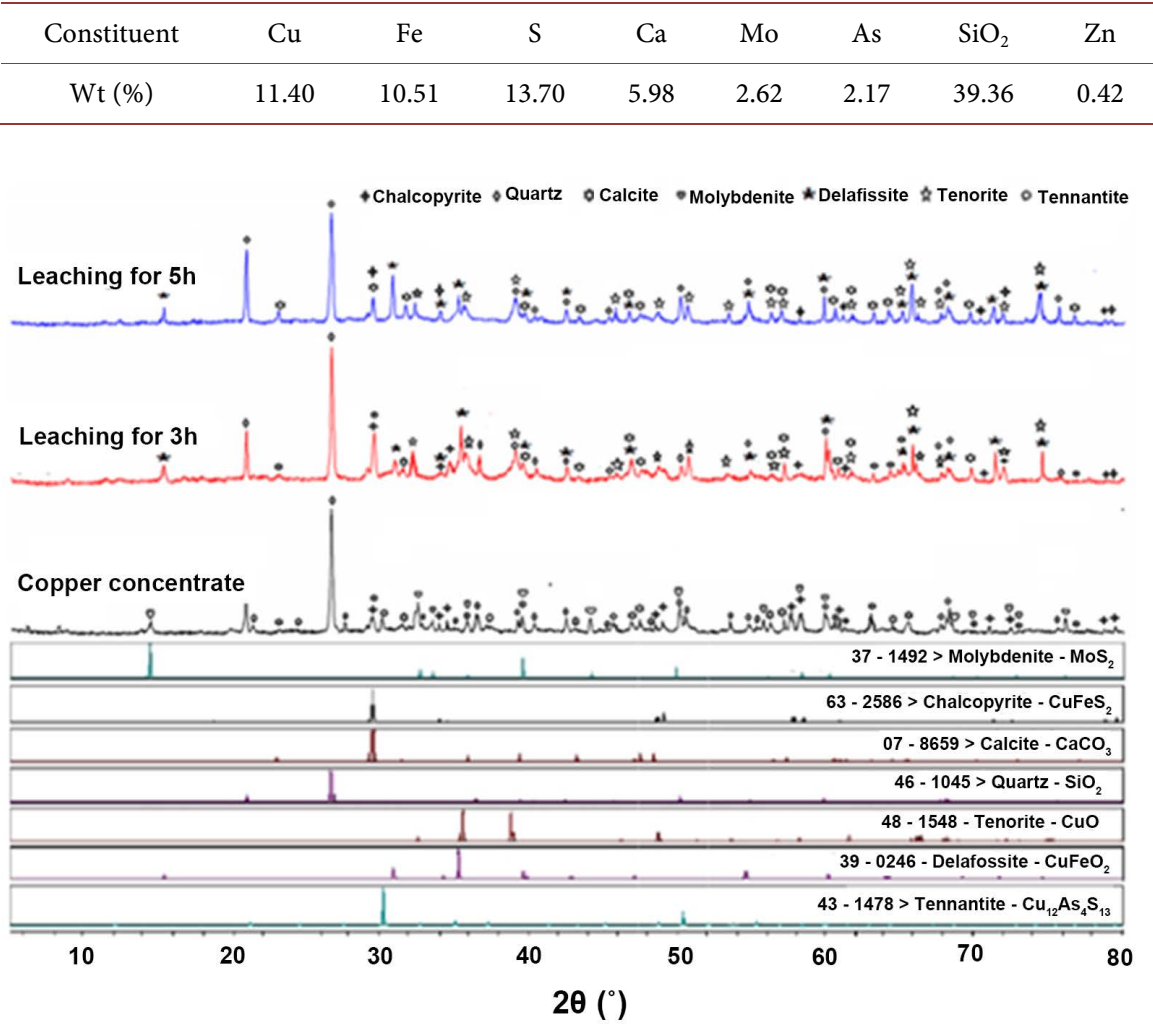

Figure 1. X-ray patterns of copper concentrate and the residues.

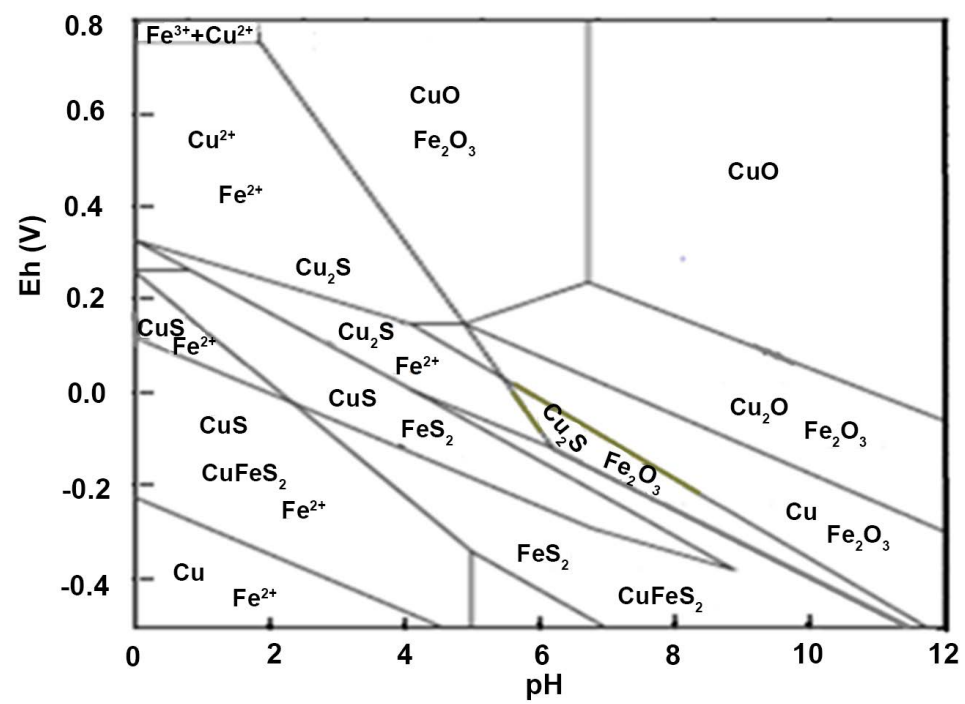

Figure 2. Eh-pH diagram for the $\mathrm{Cu}-\mathrm{Fe}-\mathrm{S}-\mathrm{H}_{2} \mathrm{O}$ system with the preponderant copper and iron species shown in each domain [19].

$\mathrm{Fe}^{2+}$ exist only in acid solution $(\mathrm{pH}<6)$ and $\mathrm{Fe}^{3+}$ exist only in acid solution $(\mathrm{pH}$ $<3$ ). A potential increase leads to the sequential alternation $\mathrm{CuFeS}_{2} \rightarrow \mathrm{Fe}_{2} \mathrm{O}_{3}$ and $\mathrm{CuS} \rightarrow \mathrm{Cu}_{2} \mathrm{~S} \rightarrow \mathrm{Cu}^{2+}$ or $\mathrm{Cu}^{+}$. In alkaline solution, as potential increases $\mathrm{CuFeS}_{2} \rightarrow \mathrm{CuS} \rightarrow \mathrm{Cu}_{2} \mathrm{~S}$ is possible and its further increase leads to the formation 
of insoluble $\mathrm{CuO}$ and $\mathrm{Fe}_{2} \mathrm{O}_{3}$.

At the same time the oxidation of $\mathrm{CuFeS}_{2}$ during oxidative alkaline leaching is difficult and complicated owing to the multilevel translation $\left(\mathrm{CuFeS}_{2} \rightarrow \mathrm{CuS} \rightarrow \mathrm{Cu}_{2} \mathrm{~S}\right)$. From thermodynamic considering, the oxidative reaction of chalcopyrite may be written as follows:

$$
4 \mathrm{CuFeS}_{2}+17 \mathrm{O}_{2}+16 \mathrm{OH}^{-}=4 \mathrm{CuO}+16 \mathrm{SO}_{4}^{2-}+2 \mathrm{Fe}_{2} \mathrm{O}_{3}+8 \mathrm{H}_{2} \mathrm{O}
$$

Copper oxide is expected to solubilize in alkaline solution via the following reaction by Wagman et al. [20].

$$
\mathrm{CuO}+(2-n) \mathrm{H}+=\mathrm{Cu}(\mathrm{OH})_{n}^{2-n}+(1-n) \mathrm{H}_{2} \mathrm{O}
$$

where $\mathrm{n}$ refers to the ionic state of hydrolysis and may present $0,1,2,3$ or 4 . As shown in Equation (2), the species of $\mathrm{CuO}$ dissolved in alkaline solution may be $\mathrm{Cu}(\mathrm{OH})_{2}, \mathrm{Cu}(\mathrm{OH})_{3}^{-}$or $\mathrm{Cu}(\mathrm{OH})_{4}^{2-}$. But $\mathrm{Cu}(\mathrm{OH})_{2}$ is a dominant aqueous species and is easily transformed into $\mathrm{CuO}$ in high alkaline solution.

The Eh-pH diagram for the behavior of $\mathrm{Cu}-\mathrm{As}-\mathrm{S}-\mathrm{H}_{2} \mathrm{O}$ system is presented in Figure 3 [21] [22]. As shown in Figure 3, the transformation of $\mathrm{Cu}_{12} \mathrm{As}_{4} \mathrm{~S}_{13} \rightarrow \mathrm{As}$ (V) takes place in the whole $\mathrm{pH}$ range from 0 to 14 under oxidizing atmosphere. In alkaline solution, the soluble states of $\mathrm{As}(\mathrm{V})$ exist as $\mathrm{H}_{2} \mathrm{AsO}_{4}^{-}, \mathrm{HAsO}_{4}^{2-}$ and $\mathrm{AsO}_{4}^{2-}$ under oxidizing atmosphere. As $\mathrm{pH}$ increases above 12, the most of As $(\mathrm{V})$ occurs as $\mathrm{AsO}_{4}^{2-}$. At the same time the transformation of copper in the tennantite will turn into $\mathrm{CuO}$ in alkaline solution under oxidizing atmosphere.

The Eh-pH diagram for the behavior of Mo-S- $\mathrm{H}_{2} \mathrm{O}$ system [23] is shown in Figure 4. It is indicated that the transformation of $\mathrm{MoS}_{2} \rightarrow \mathrm{Mo}$ (VI) takes place in the whole $\mathrm{pH}$ range from 0 to 14 . Reaction of Mo (VI) in aqueous solution can be deemed as a complex formation of between $\mathrm{MoO}_{4}^{2-}$ and $\mathrm{H}^{+}$. In alkaline solution, the concentrate of hydrogen ion is so low that most of Mo (VI) occurs as monomeric $\mathrm{MoO}_{4}^{2-}$ [24].

The Eh-pH diagram for the behavior of $\mathrm{Zn}-\mathrm{S}-\mathrm{H}_{2} \mathrm{O}$ [25] system is also given in Figure 5. It shows the thermodynamically stales of the forms of zinc in aqueous. In the $\mathrm{Zn}-\mathrm{S}-\mathrm{H}_{2} \mathrm{O}$ system, the soluble states of zinc exist as $\mathrm{Zn}^{2+}$ and $\mathrm{ZnO}_{2}^{2-}$ in solution. As $\mathrm{pH}$ of the solution is above 13, the most of soluble state of zinc exists $\mathrm{ZnO}_{2}^{2-}$, which means that $\mathrm{ZnS}$ can be oxidized in alkaline leaching under oxygen.

\subsection{Removal Behaviors of Metallic Impurities of Off-Grade Copper Concentrate}

\subsubsection{Effect of Temperature on the Removal of Metallic Impurities}

$\mathrm{H}_{2} \mathrm{O}_{2}$ is thermolabile, and higher temperatures are generally favorable for leaching from the perspective of leaching kinetics, therefore, the temperature was researched in the range of $20^{\circ} \mathrm{C}$ to $70^{\circ} \mathrm{C}$ under the other constant conditions of $\mathrm{NaOH} 1.5 \mathrm{~mol} / \mathrm{L}, \mathrm{H}_{2} \mathrm{O}_{2} 1.0 \mathrm{~mol} / \mathrm{L}$, leaching time $5 \mathrm{~h}$, and liquid to solid ratio $5 / 1$ $\mathrm{mL} / \mathrm{g}$. The experimental results are presented in Figure 6 .

The extractions of Mo, As and $\mathrm{Zn}$ increase from $49.2 \%$ to $95.6 \%, 38.9 \%$ to $93.4 \%, 45.3 \%$ to $94.4 \%$, respectively, when the temperature increases from 


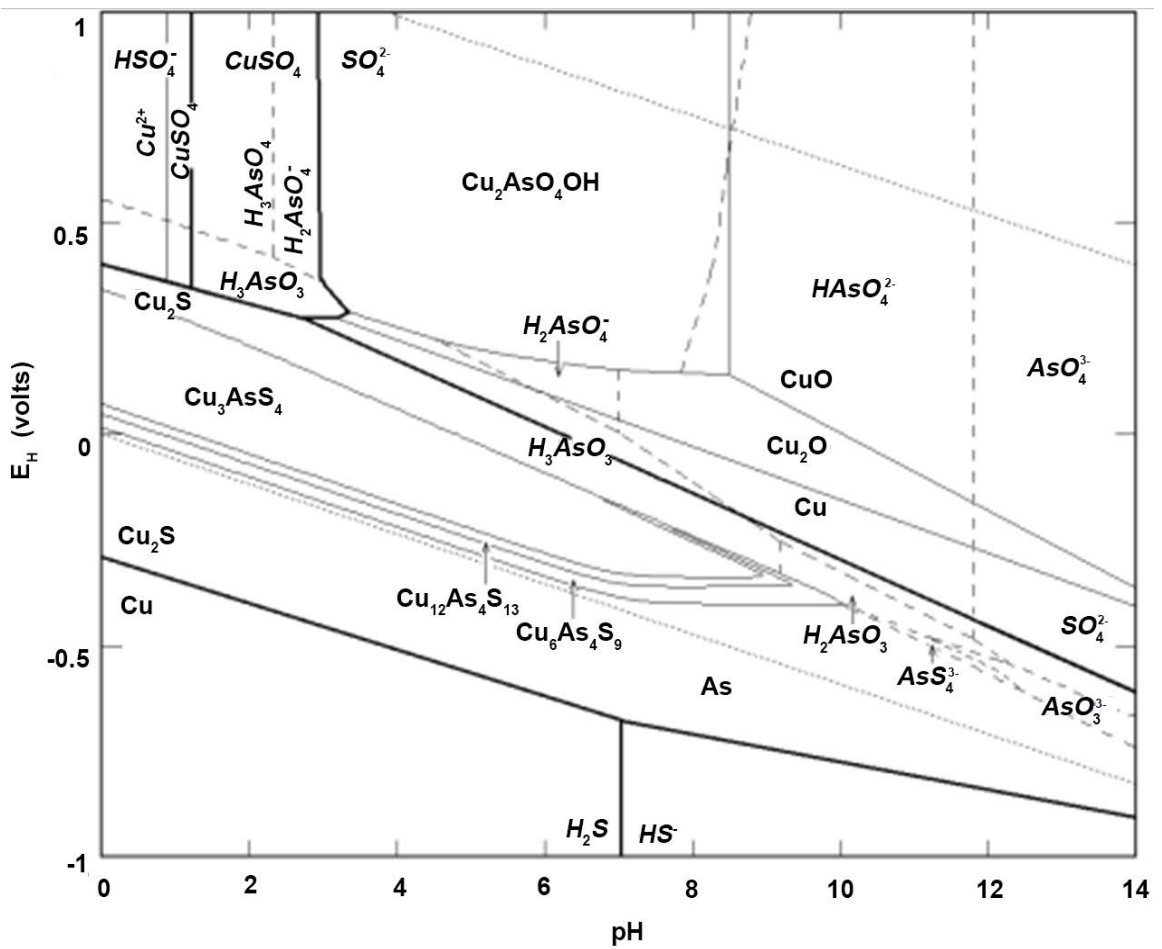

Figure 3. Eh-pH diagram for the $\mathrm{Cu}-\mathrm{As}-\mathrm{S}-\mathrm{H}_{2} \mathrm{O}$ system with $[\mathrm{Cu}]=0.075 \mathrm{M}$, $[\mathrm{As}]=0.025$ $\mathrm{M},[\mathrm{S}]=0.1 \mathrm{M}$. Sulfur oxidation includes all sulfoxy species [21] [22].

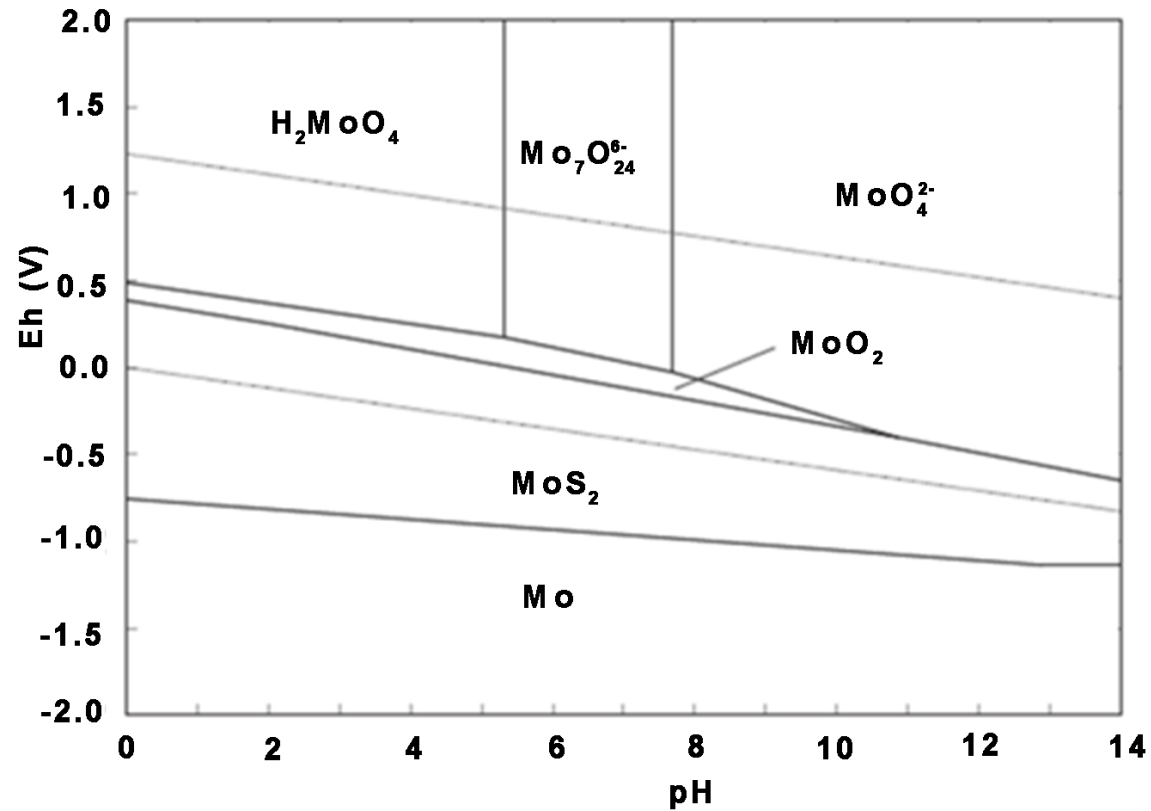

Figure 4. Eh-pH diagram for the $\mathrm{Mo}-\mathrm{S}-\mathrm{H}_{2} \mathrm{O}$ system at $25^{\circ} \mathrm{C}$ with $[\mathrm{Mo}]=1 \mathrm{~mol} / \mathrm{kg}$ and $[\mathrm{S}]=1 \mathrm{~mol} / \mathrm{kg}$ dawn using HSC chemistry software [23].

$20^{\circ} \mathrm{C}$ to $50^{\circ} \mathrm{C}$. The extractions of Mo, As and $\mathrm{Zn}$ plateau $95.6 \%, 93.4 \%$, and $94.4 \%$, respectively, at $60^{\circ} \mathrm{C}$, and then decrease to $86.9 \%, 84.9 \%$ and $88.2 \%$, respectively, when the temperature was increased to $70^{\circ} \mathrm{C}$. These results indicate the optimum effect of $\mathrm{H}_{2} \mathrm{O}_{2}$ for the oxidation of $\mathrm{CuFeS}_{2}, \mathrm{MoS}_{2}$ and $\mathrm{ZnS}$ is 


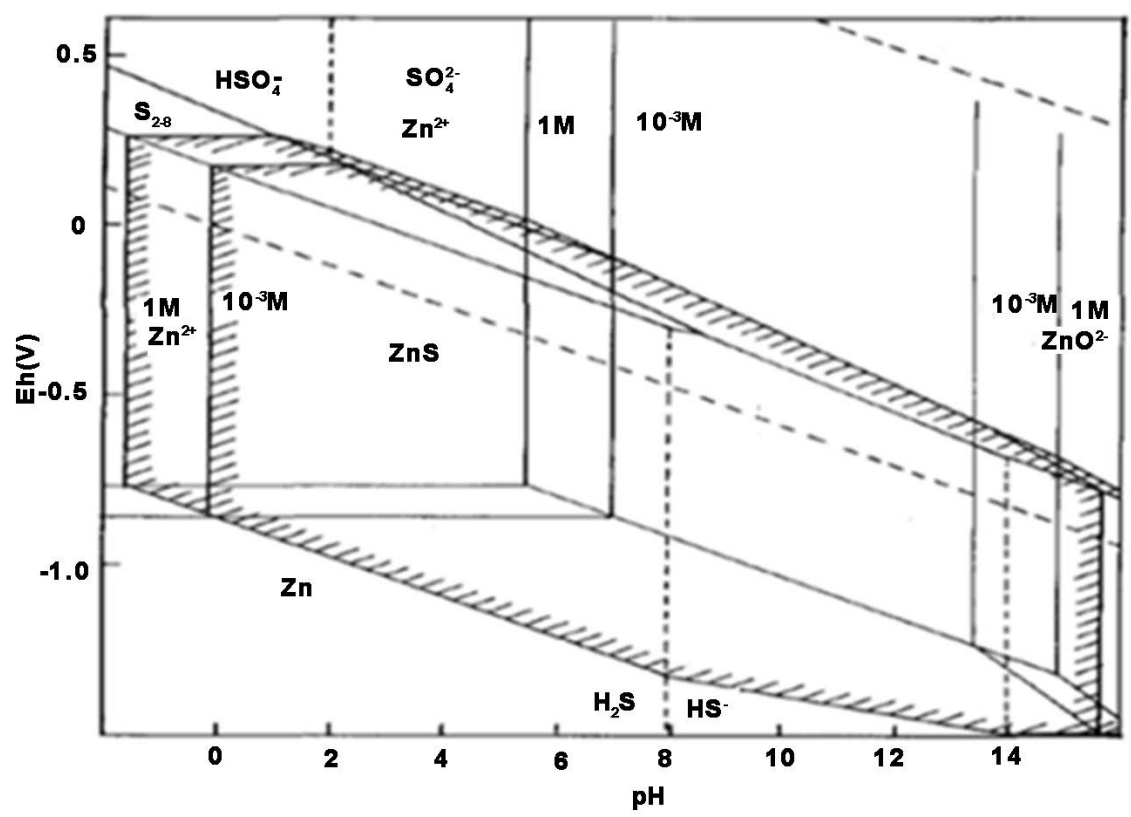

Figure 5. Eh-pH diagram for the $\mathrm{Zn}-\mathrm{S}-\mathrm{H}_{2} \mathrm{O}$ system at $25^{\circ} \mathrm{C}$ standard condition [25].

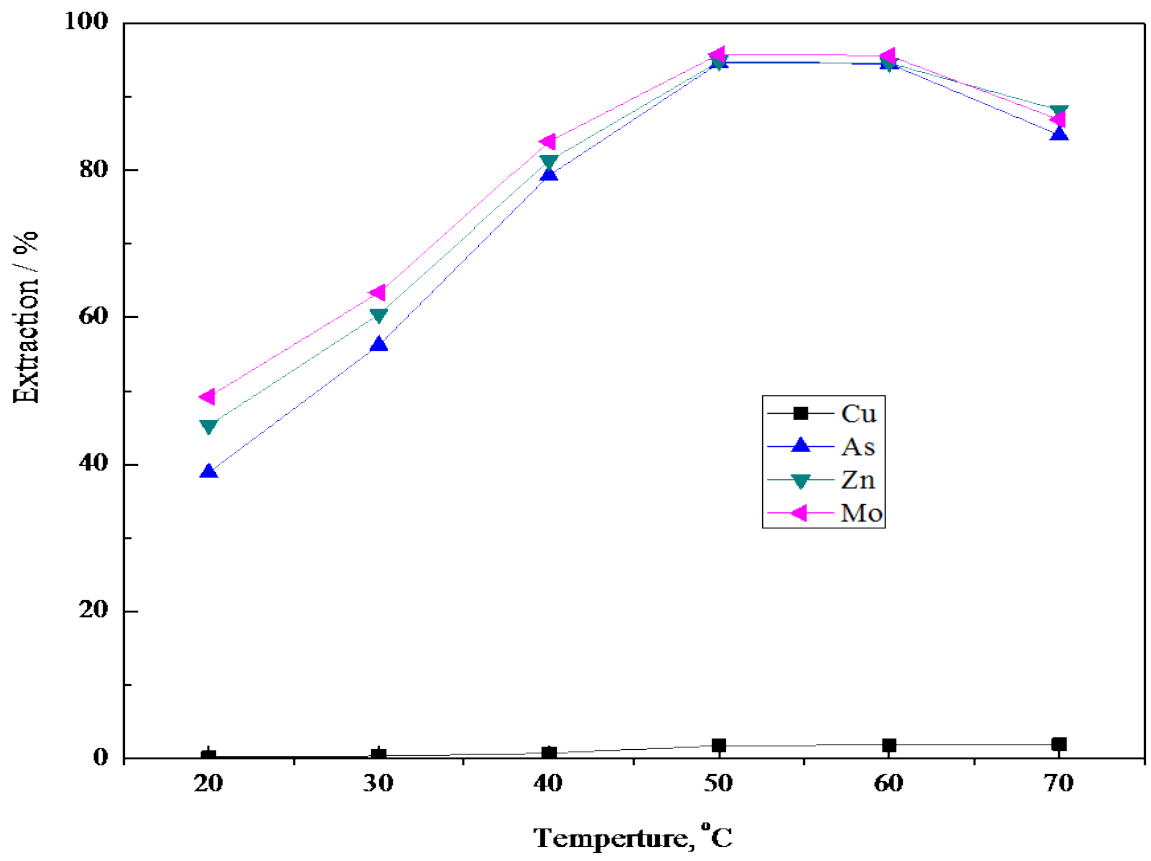

Figure 6. Effect of temperature on the leaching of metals.

obtained at $50^{\circ} \mathrm{C}$, whereas at temperatures higher than $60^{\circ} \mathrm{C}$ and peculiarly at $70^{\circ} \mathrm{C}, \mathrm{H}_{2} \mathrm{O}_{2}$ was resolved too early due to the high temperature and did not act a role in the oxidation [26], with a large amount of tiny bubbles produce immediately after the addition of $\mathrm{H}_{2} \mathrm{O}_{2}$, which means that the concentration of $\mathrm{H}_{2} \mathrm{O}_{2}$ will decrease rapidly in the solution and this will lower the kinetics of the leaching process. The dissolution of copper increase in the temperature range of $20^{\circ} \mathrm{C}$ to $70^{\circ} \mathrm{C}$, but it only reaches a maximum of $1.95 \%$ at $70^{\circ} \mathrm{C}$. Thus $50^{\circ} \mathrm{C}$ with a ex- 
traction of $\mathrm{Cu} 1.75 \%$ was selected as the optimum temperature for the subsequent experiments.

\subsubsection{Effect of Leaching Time on the Removal of Metallic Impurities}

The influence of the leaching time on $\mathrm{Cu}, \mathrm{Mo}$, As and $\mathrm{Zn}$ extraction was investigated at $\mathrm{NaOH} 1.5 \mathrm{~mol} / \mathrm{L}, \mathrm{H}_{2} \mathrm{O}_{2} 1.0 \mathrm{~mol} / \mathrm{L}$ temperature $50^{\circ} \mathrm{C}$, and liquid to solid ratio $5 / 1 \mathrm{~mL} / \mathrm{g}$. The result is given in Figure 7. About $96 \% \mathrm{Mo}, 93 \%$ As and 94\% $\mathrm{Zn}$ were leached after $5 \mathrm{~h}$. Further prolonging leaching duration give no significant increase in As and $\mathrm{Zn}$ extraction, which means that $5 \mathrm{~h}$ is enough to leach Mo, As and $\mathrm{Zn}$ from copper concentrate. In spite that the copper extraction increases with the extension of leaching time, the overall is also less than $2.07 \%$ within $7 \mathrm{~h}$.

\subsubsection{Effect of Sodium Hydroxide Concentration on the Removal of Metallic Impurities}

In order to study the effects of $\mathrm{NaOH}$ concentration on the extraction of Mo, As and $\mathrm{Zn}$, and the dissolution of copper. $\mathrm{NaOH}$ concentration was varied from 0.5 to $2.5 \mathrm{~mol} / \mathrm{L}$, while liquid to solid ratio $5 / 1 \mathrm{~mL} / \mathrm{g}, \mathrm{H}_{2} \mathrm{O}_{2} 1.0 \mathrm{~mol} / \mathrm{L}$, leaching time $5 \mathrm{~h}$ and temperature $50^{\circ} \mathrm{C}$. The results are shown in Figure 8. The extractions of Mo, As and $\mathrm{Zn}$ increase from $72.2 \%$ to $95.8 \%, 66.5 \%$ to $93.4 \%, 58.4 \%$ to $94.3 \%$, respectively, when the $\mathrm{NaOH}$ concentration rises from $0.5 \mathrm{~mol} / \mathrm{L}$ to $1.5 \mathrm{~mol} / \mathrm{L}$. Even when $\mathrm{NaOH}$ concentration further increases, the extractions of As and $\mathrm{Zn}$ show no significant difference. On the other hand, it is also observed in Fig. 8 that the Mo extraction decreases slightly with the rise of $\mathrm{NaOH}$ concentration, which was is good agreed with the results obtained by several researchers [27] [28]. It can be explained that Mo (VI) in the solution can be absorbed by $\mathrm{Fe}_{2} \mathrm{O}_{3}$ produced much in situ precipitation. In spite that the $\mathrm{Cu}$ extraction increases with increasing the $\mathrm{NaOH}$ concentration from 0.5 to $2.5 \mathrm{~mol} / \mathrm{L}$, the maximum extraction of $\mathrm{Cu}$ is only $2.05 \%$ at $\mathrm{NaOH} 2.5 \mathrm{~mol} / \mathrm{L}$. Therefore, sodium hydroxide concentration $1.5 \mathrm{~mol} / \mathrm{L}$ was chosen as for the subsequent experiments.

\subsubsection{Effect of Hydrogen Peroxide Concentration on the Removal of Metallic Impurities}

The influence of $\mathrm{H}_{2} \mathrm{O}_{2}$ concentration on the removal of metallic impurities was investigated at $\mathrm{NaOH} 1.5 \mathrm{~mol} / \mathrm{L}$, liquid/solid ratio $5 / 1 \mathrm{~mL} / \mathrm{g}$, leaching time $5 \mathrm{~h}$ and temperature $50^{\circ} \mathrm{C}$. As presented in Figure 9, the extraction of Mo, As and $\mathrm{Zn}$ is higher than that of $\mathrm{Cu}$ in these experiments, which can be explained by the Eh-pH diagrams of Cu-Fe-S- $\mathrm{H}_{2} \mathrm{O}$, Cu-As-S- $\mathrm{H}_{2} \mathrm{O}$, Mo-S- $\mathrm{H}_{2} \mathrm{O}$ and $\mathrm{Zn}-\mathrm{S}-\mathrm{H}_{2} \mathrm{O}$ systems, respectively, for the oxidative leaching behaviors of metals in the copper concentrate.

The standard reduction potential of $\mathrm{H}_{2} \mathrm{O}_{2}\left(\mathrm{E}_{\mathrm{H}_{2} \mathrm{O}_{2} / \mathrm{OH}^{-}}^{\theta}=0.87 \mathrm{~V}\right)$ is higher than that of $\mathrm{O}_{2}\left(\mathrm{E}_{\mathrm{O}_{2} / \mathrm{OH}^{-}}^{\theta}=0.401 \mathrm{~V}\right)$, therefore using $\mathrm{H}_{2} \mathrm{O}_{2}$ as an oxidant instead of oxygen, the oxidation reactions of $\mathrm{CuFeS}_{2}, \mathrm{Cu}_{12} \mathrm{As}_{4} \mathrm{~S}_{13}, \mathrm{MoS}_{2}$ and $\mathrm{ZnS}$ can take place as follows:

$$
4 \mathrm{CuFeS}_{2}+34 \mathrm{H}_{2} \mathrm{O}_{2}+16 \mathrm{OH}^{-}=4 \mathrm{CuO}+16 \mathrm{SO}_{4}^{2-}+2 \mathrm{Fe}_{2} \mathrm{O}_{3}+42 \mathrm{H}_{2} \mathrm{O}
$$




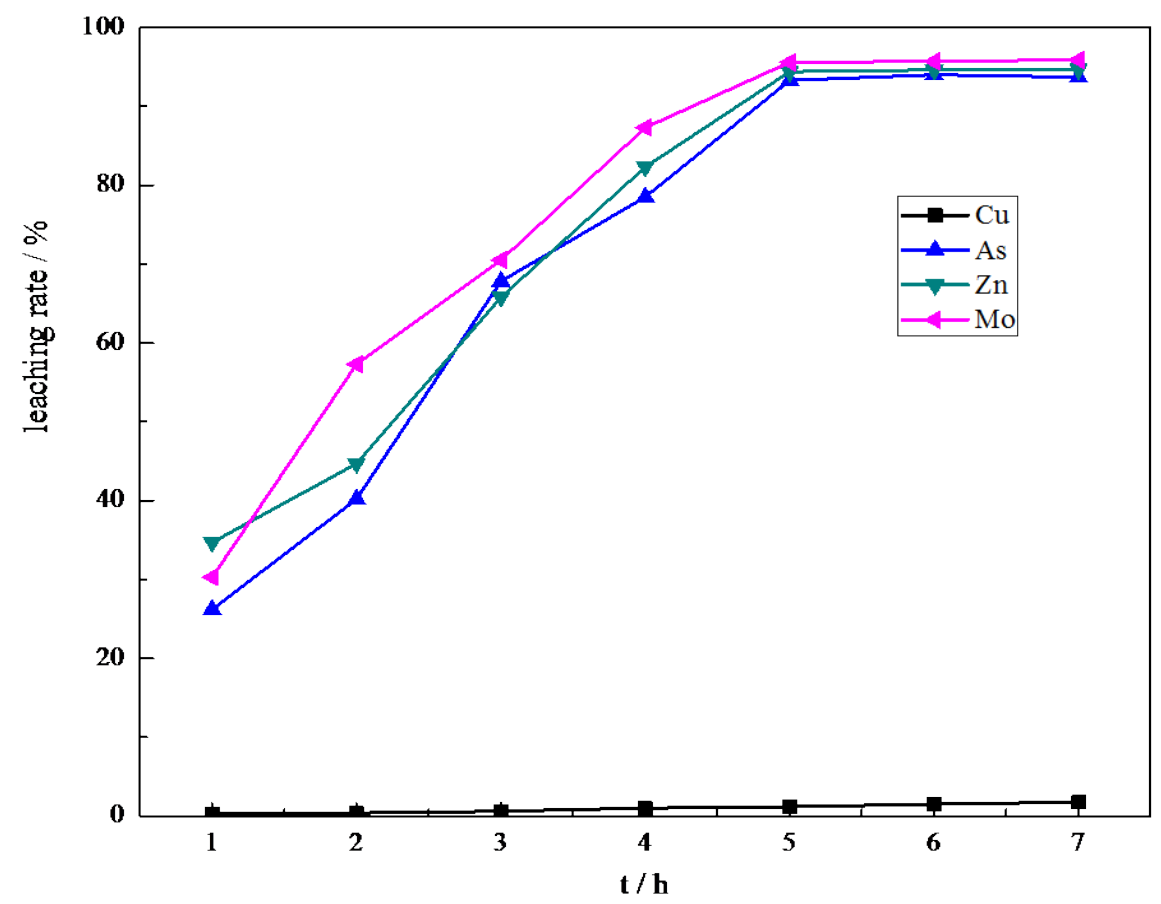

Figure 7. Effect of leaching time on the leaching of metals.

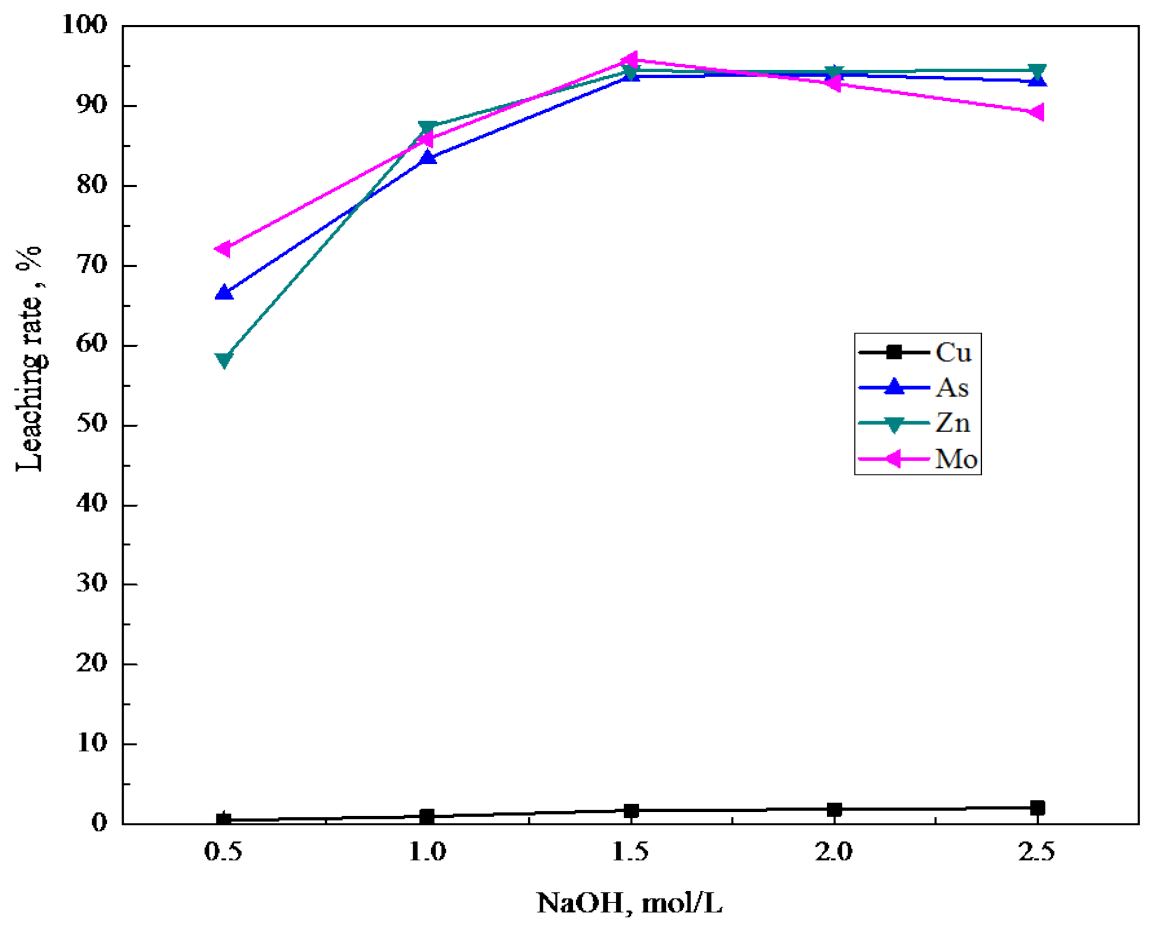

Figure 8. Effect of sodium hydroxide on the leaching of metals.

$$
\begin{gathered}
\mathrm{S}_{13}+68 \mathrm{H}_{2} \mathrm{O}_{2}+24 \mathrm{OH}^{-}=12 \mathrm{CuO}+4 \mathrm{AsO}_{4}^{3-}+80 \mathrm{H}_{2} \mathrm{O}+13 \mathrm{SO}_{4}^{2-} \\
\mathrm{MoS}_{2}+6 \mathrm{OH}^{-}+9 \mathrm{H}_{2} \mathrm{O}_{2}=\mathrm{MoO}_{4}^{2-}+2 \mathrm{SO}_{4}^{2-}+12 \mathrm{H}_{2} \mathrm{O} \\
\mathrm{ZnS}+4 \mathrm{H}_{2} \mathrm{O}_{2}+4 \mathrm{OH}^{-}=\mathrm{ZnO}_{2}^{2-}+\mathrm{SO}_{4}^{2-}+6 \mathrm{H}_{2} \mathrm{O}
\end{gathered}
$$




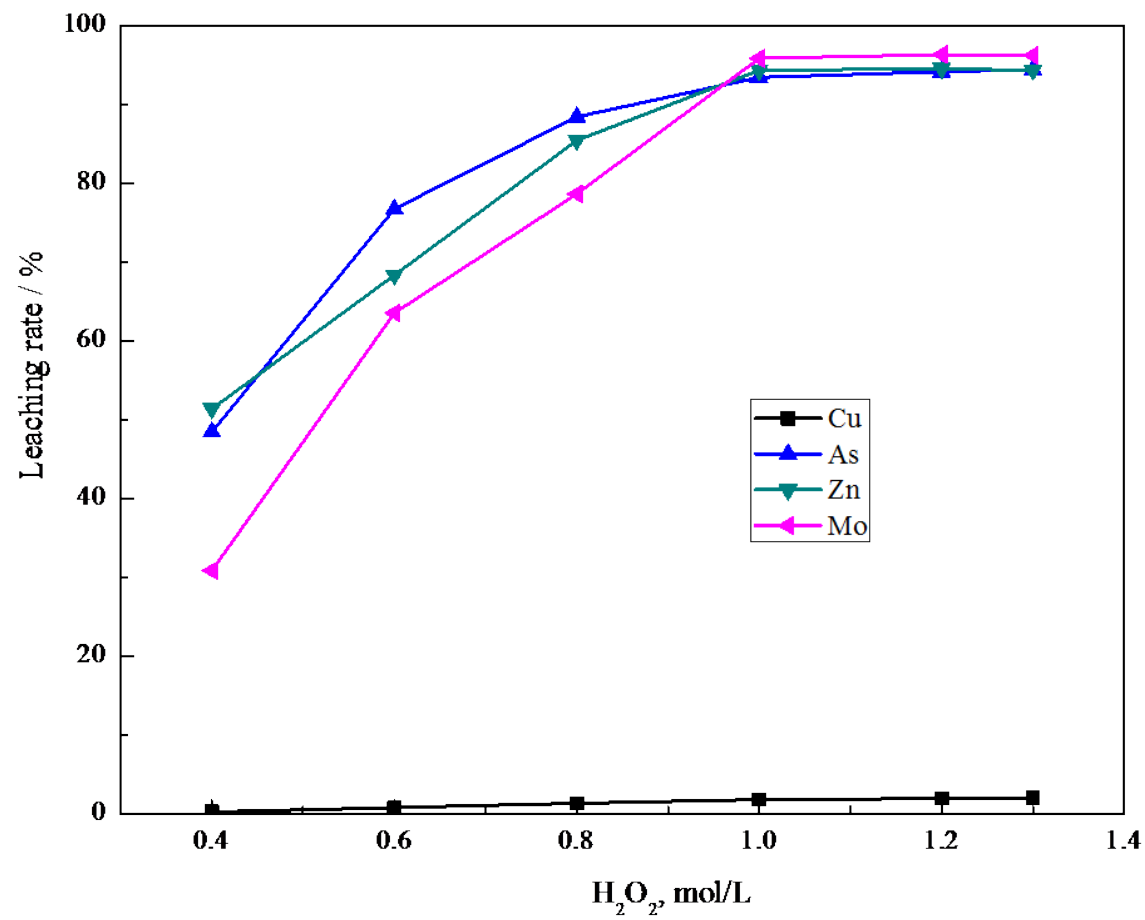

Figure 9. Effect of hydrogen peroxide on the leaching of metals.

The extraction of Mo, As and $\mathrm{Zn}$ increase from $30.8 \%$ to $95.7 \%, 48.4 \%$ to $93.4 \%$ and $51.3 \%$ to $94.4 \%$, respectively, when hydrogen peroxide concentration increases from $0.4 \mathrm{~mol} / \mathrm{L}$ to $1.0 \mathrm{~mol} / \mathrm{L}$. However there is no significant change on the extraction of $\mathrm{Mo}$, As and $\mathrm{Zn}$ when the hydrogen peroxide concentration is above $1.0 \mathrm{~mol} / \mathrm{L}$. Although the $\mathrm{Cu}$ extraction increases with the rise of $\mathrm{H}_{2} \mathrm{O}_{2}$ concentration, the maximum $\mathrm{Cu}$ extraction is only $2.0 \%$ at $\mathrm{H}_{2} \mathrm{O}_{2} 1.3 \mathrm{~mol} / \mathrm{L}$. Considering the economic factor, the optimum $\mathrm{H}_{2} \mathrm{O}_{2}$ concentration is fixed at $1.0 \mathrm{~mol} / \mathrm{L}$ for the subsequent experiments.

\subsubsection{Effect of Liquid to Solid Ratio on the Removal of Metallic Impurities}

The effect of liquid to solid ratio on the removal of $\mathrm{Mo}, \mathrm{As}, \mathrm{Zn}$ and $\mathrm{Cu}$ was investigated under the conditions of sodium hydroxide $1.5 \mathrm{~mol} / \mathrm{L}$, hydrogen peroxide $1.0 \mathrm{~mol} / \mathrm{L}$, leaching time $5 \mathrm{~h}$ and temperature $50^{\circ} \mathrm{C}$. The results are given in Figure 10. The extractions of Mo, As and $\mathrm{Zn}$ increase along with increasing the liquid to solid ratio from 2 to $5 \mathrm{~mL} / \mathrm{g}$, maximize to $95.8 \%, 93.4 \%$ and $94.4 \%$, respectively, at the ratio of $5 \mathrm{~mL} / \mathrm{g}$ and then decrease slightly. $\mathrm{Cu}$ extraction also decreases distinctly with the rise of liquid to solid ratio. The lower dissolved fractions of $\mathrm{Mo}, \mathrm{As}, \mathrm{Zn}$ and $\mathrm{Cu}$ can be explained by the fact that at higher liquid to solid ratio, more quartz reacts with $\mathrm{NaOH}$ to form the thick slurry, which can postpone the mass diffusion in the liquid-solid phase system. This similarly result is reported in the oxidative alkaline leaching of Ni-Mo ore by Wang et al. [23]. At the same time, it is found that Si extraction increases from $10.34 \%$ to $26.23 \%$ during the leaching when the liquid to solid ratio rise from 5 to $9 \mathrm{~mL} / \mathrm{g}$. considering this fact, the liquid to solid ratio $5 \mathrm{~mL} / \mathrm{g}$ was selected. 


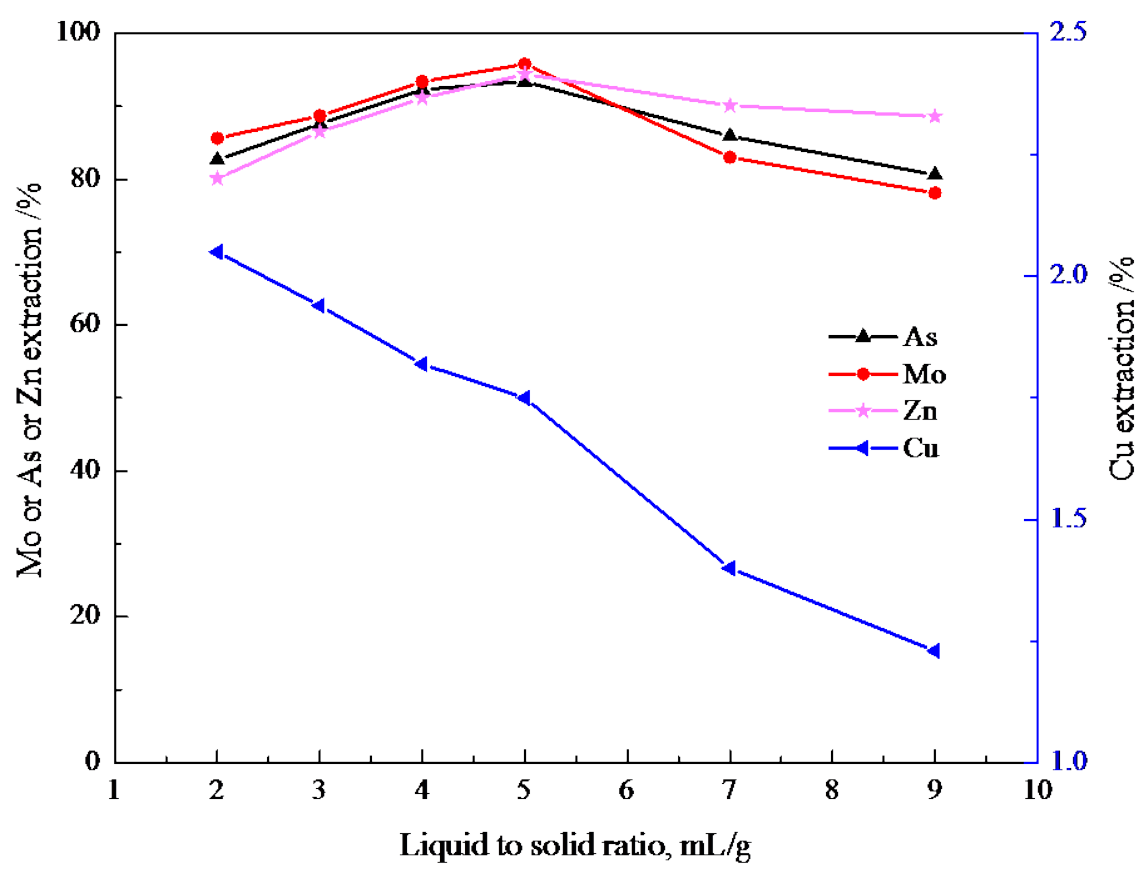

Figure 10. Effect of sodium hydroxide on the leaching of metals.

\subsection{Morphology of the Leach Residues}

According to the above results, the optimum conditions for selective extraction of Mo, As and $\mathrm{Zn}$ from off-grade copper concentrate are listed as follows: $\mathrm{NaOH}$ concentration of $1.5 \mathrm{~mol} / \mathrm{L}, \mathrm{H}_{2} \mathrm{O}_{2}$ concentration of $1.0 \mathrm{~mol} / \mathrm{L}$, temperature $50^{\circ} \mathrm{C}$, liquid to solid ratio of $5 / 1 \mathrm{~mL} / \mathrm{g}$, leaching time $5 \mathrm{~h}$. Under these conditions, the Mo, As and Zn extractions are up to about $95.8 \%, 93.4 \%$ and $94.4 \%$, respectively, and only $1.74 \% \mathrm{Cu}$ was dissolved into the solution.

Figure 1 shows the XRD results of the residues leaching for $3 \mathrm{~h}$ and $5 \mathrm{~h}$ at the optimum other conditions. Compared with the XRD pattern of original concentrate (Figure 1), the peaks of molybdenite and tennantite in the residues have disappeared, which indicate that tennantite and molybdenite can be oxidized completely. There occur as new phases including tenorite $(\mathrm{CuO})$ and delafissite $\left(\mathrm{CuFeO}_{2}\right)$ in the residues. According to the reaction Equations (6) and (7), tenorite could produced from the oxidation of chalcopyrite and tennantite. If Equation (6) could takes place, there exist $\mathrm{CuO}$ and $\mathrm{F}_{2} \mathrm{O}_{3}$ in the residues, however $\mathrm{F}_{2} \mathrm{O}_{3}$ formed could not detected in the residues by $\mathrm{X}$-ray diffraction method. This may be attributed to a fact that $\mathrm{F}_{2} \mathrm{O}_{3}$ is amorphous. However there occurs as a new delafissite in the residues, it is thought to originate from the oxidation of chalcopyrite. A chalcopyrite electrode was studied by Electrochemical Impedance Spectroscopy in an alkaline solution for different oxidation potentials by Velásquez et al. [29]. This result shows that the $\mathrm{CuFeO}_{2}$ on the surface of chalcopyrite can be formed by an oxidation process $(+0.8 \mathrm{~V}$ vs. SCE). The standard reduction potential of $\mathrm{H}_{2} \mathrm{O}_{2}\left(\mathrm{E}^{\theta} \mathrm{H}_{2} \mathrm{O}_{2} / \mathrm{OH}^{-}=0.87 \mathrm{~V}\right)$ exceeds $0.8 \mathrm{~V}$, it is possible that chalcopyrite was oxidized to form $\mathrm{CuFeO}_{2}$ during alkaline leaching process. And the oxidation of chalcopyrite could be taken place as follows: 


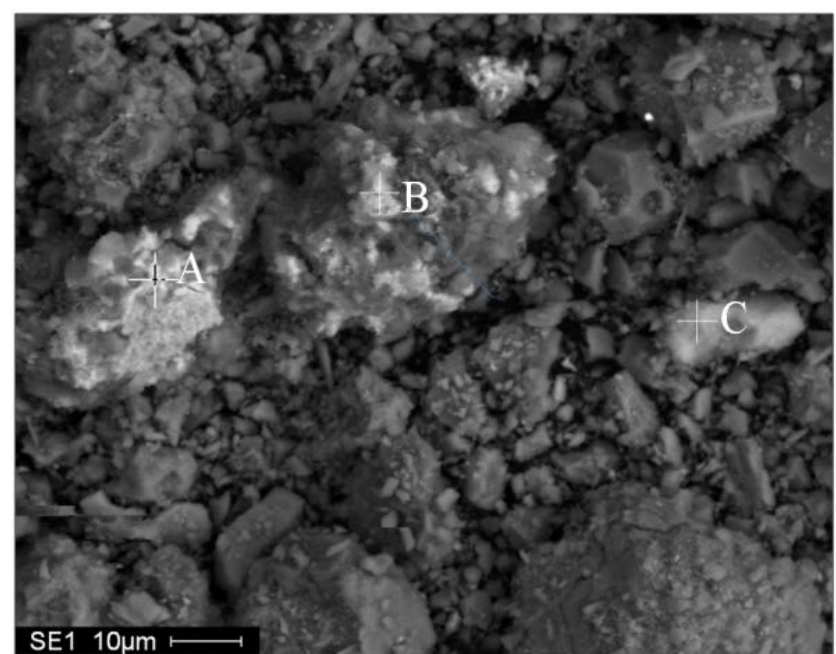

(a)

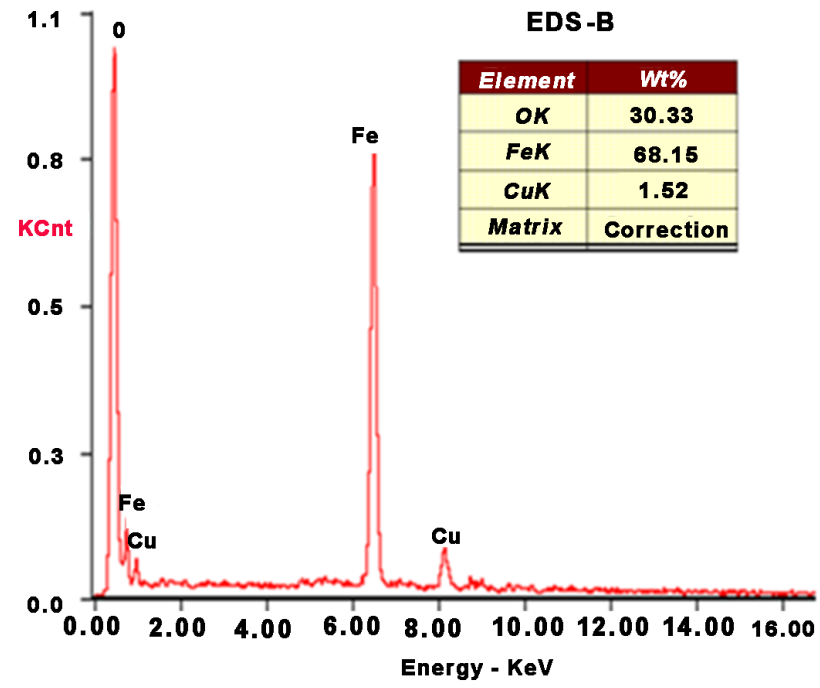

(c)

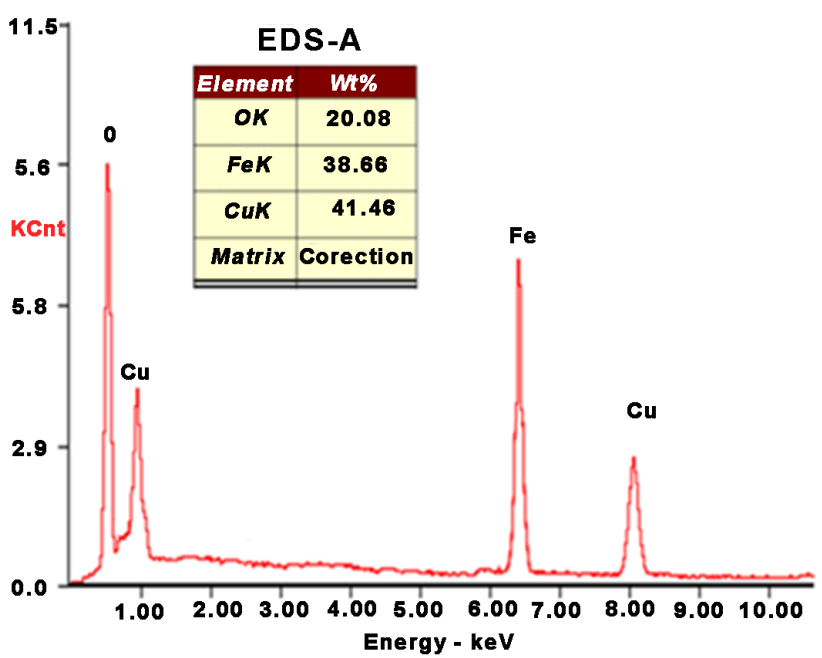

(b)

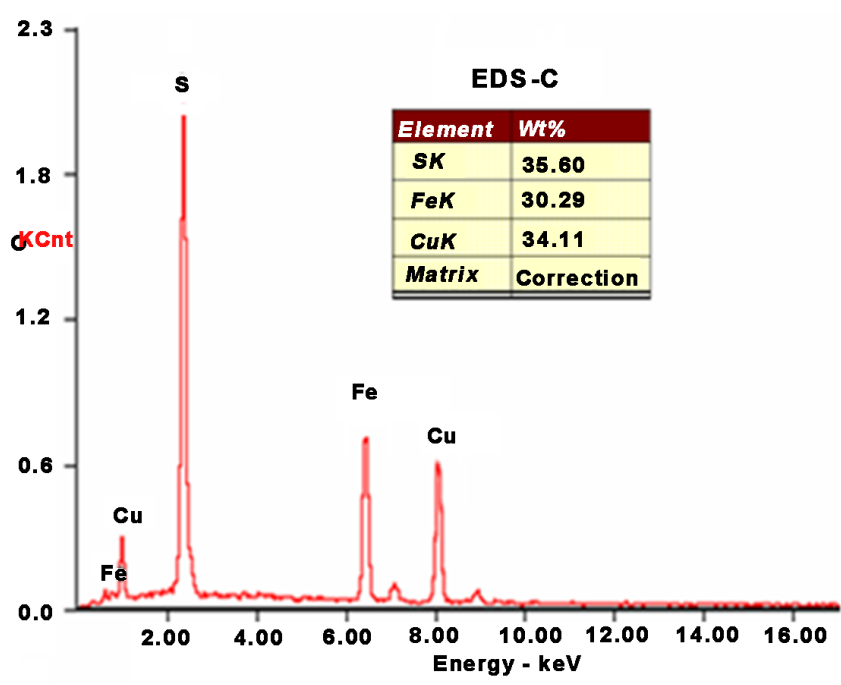

(d)

Figure 11. The SEM-EDS results determined on the cross-section of the residue: (a) $\mathrm{CuFeO}_{2}$, (b) $\mathrm{Fe}_{2} \mathrm{O}_{3}$ and (c) $\mathrm{CuFeS}_{2}$.

$$
\mathrm{CuFeS}_{2}+7 \mathrm{H}_{2} \mathrm{O}_{2}+4 \mathrm{NaOH}^{-}=\mathrm{CuFeO}_{2}+2 \mathrm{Na}_{2} \mathrm{SO}_{4}+9 \mathrm{H}_{2} \mathrm{O}
$$

In order to further understand the oxidation mechanism of chalcopyrite, the microscopic structure of the residue and the chemical compositions of the points analyzed by SEM coupled with EDS, are presented in Figure 11. The SEM result indicates that the surface structures of primary particles have a porous and rough surface morphology. As can be seen from Figure 11. EDS-A, B, C, The EDS analysis results show that the elements distributed at the points $\mathrm{A}, \mathrm{B}$ and $\mathrm{C}$ are close to the theoretical elemental contents of $\mathrm{CuFeO}_{2}$ (w.t. $36.9 \% \mathrm{Fe}$, w.t. $41.2 \%$ w.t. $\mathrm{Cu}, 21.1 \% \mathrm{O}$ ), $\mathrm{Fe}_{2} \mathrm{O}_{3}$ (w.t. $69.8 \% \mathrm{Fe}$, w.t. $30.2 \% \mathrm{O}$ ) and $\mathrm{CuFeS}_{2}$ (w.t. $30.4 \% \mathrm{Fe}$, w.t. $34.6 \% \mathrm{Cu}$, w.t. $35.0 \% \mathrm{O}$ ), respectively, namely, it indicates that the phases of mocro-area $\mathrm{A}, \mathrm{B}$ and $\mathrm{C}$ occur as delafissite, $\mathrm{Fe}_{2} \mathrm{O}_{3}$ and chalcopyrite, respectively. These results show that chalcopyrite can oxidize simultaneously as 
the Equations (6) and (10) in alkaline solution containing $\mathrm{H}_{2} \mathrm{O}_{2}$.

\section{Conclusions}

The studies have been carried out to up-grade the copper concentrate. These impurities of Mo, As and $\mathrm{Zn}$ were leached mainly in alkaline solution containing hydrogen peroxide.

The oxidative mechanisms of chalcopyrite, tennantite and molybdenite in the copper concentrate were demonstrated by methods of XRD and SEM-EDS analysis, especially the chalcopyrite oxidation simultaneously takes place as Equations (6) and (10):

$$
\begin{gathered}
4 \mathrm{CuFeS}_{2}+34 \mathrm{H}_{2} \mathrm{O}_{2}+16 \mathrm{OH}^{-}=4 \mathrm{CuO}+16 \mathrm{SO}_{4}^{2-}+2 \mathrm{Fe}_{2} \mathrm{O}_{3}+42 \mathrm{H}_{2} \mathrm{O} \\
\mathrm{CuFeS}_{2}+7 \mathrm{H}_{2} \mathrm{O}_{2}+4 \mathrm{NaOH}^{-}=\mathrm{CuFeO}_{2}+2 \mathrm{Na}_{2} \mathrm{SO}_{4}+9 \mathrm{H}_{2} \mathrm{O}
\end{gathered}
$$

About $95.80 \%$ Mo, 93.4\% As, and $94.4 \% \mathrm{Zn}$ can be removed under the optional conditions: sodium hydroxide $1.5 \mathrm{~mol} / \mathrm{L}$, hydrogen peroxide $1.0 \mathrm{~mol} / \mathrm{L}$, temperature $50^{\circ} \mathrm{C}$, liquid to solid ratio $5 / 1 \mathrm{~mL} / \mathrm{g}$ and leaching time $5 \mathrm{~h}$.

\section{Acknowledgements}

This work was financially supported by the National Natural Science Foundation of China (Grant No. 51364009), Key Research Projects of Education Department of Hunan Province (Grant No. 15A151), Natural Science Foundation of Hunan Province (Grant No. 2015JJ2115), Teaching Reform Projects of Education Department of Hunan Province (Grant No. 20150228) and Teaching Reform Projects of Jishou University (Grant No. 2015003).

\section{References}

[1] Zheng, W., Mao, J.-W., Pirajno, F., Zhao, H.-J., Zhao, C.-S., Mao, Z.-H. and Wang,Y.-J. (2015) Geochronology and Geochemistry of the Shilu Cu-Mo Deposit in the Yunkai Area, Guangdong Province, South China and Its Implication. Ore Geology Reviews, 67, 382-398. https://doi.org/10.1016/j.oregeorev.2014.12.009

[2] Hu, Y.-B., Liu, J.-Q., Ling, M.-X., Ding, W., Liu, Y., Zartman, R.E., Ma, X.-F., Liu, D.-Y., Zhang, C.-C., Sun, S.-J., Zhang, L.-P., Wu, K. and Sun, W.-D. (2015) The Formation of Qulong Adakites and Their Relationship with Porphyry Copper Deposit: Geochemical Constraints. Lithos, 220-223, 60-80. https://doi.org/10.1016/j.lithos.2014.12.025

[3] Wu, G., Chen, Y.-C., Li, Z.-Y., Li, J., Yang, X.-S. and Qiao, C.-J. (2014) Geochronology and Fluid Inclusion Study of the Liu Yinjiagou Porphyry-Skarn Mo-Cu-Pyrite Deposit in the East Qinling Orogenic Belt, China. Journal of Asian Earth Sciences, 79, 585-607. https://doi.org/10.1016/j.jseaes.2013.08.032

[4] Chen, X.-L., Yan, Y.-F., Ye, L. and Su, C.-X. (2012) Characteristics of Ore-Forming Liquid of Damajianshan Cu-As Deposit in Luchun, Honghe of Yunnan. Mineral Resources and Geology, 26, 148-152.

[5] Liu, J.-J., Yang, D., Liu, Z.J., Yang, Y. and Mao, G.J. (2008) Mineralogical Characteristics and Genetic Significance of Sulvanite from the Large Barium Metallogenic Belt South Qinling Mountains, China. Journal of Mineral \& Petrol, 28, 44-50 (In 
Chinese).

[6] Cao, Z.F., Zhong, H., Liu, G.Y., Wang, S. and Xia, L.Y. (2012) Efficient Flatation Tests on Peru As-Containing Cu-Mo Ore. Rare Metals and Cemented Carbides, 40, 1-4 (In Chinese).

[7] Tan, X., He, F.Y. and Tan, X (2015) Flotation Tests on Flotation Tailings of a Copper-Molybdenum Ore. Mining and Metallurgy, 24, 1-6 (In Chinese).

[8] Baxter, K., Scriba, H. and Vega, I. (2010) Treatment of High-Arsenic Copper-Gold Concentrates-An Options Review. Proceedings of Copper 2010, 5, 1783-1802.

[9] Ruiz, M.C., Grandon, L. and Padilla, R. (2014) Selective Arsenic Removal from Enargite by Alkaline Digestion and Water Leaching. Hydrometallurgy, 150, 20-26. https://doi.org/10.1016/j.hydromet.2014.09.004

[10] Mihajlovic, I., Strbac, N., Zivkovik, Z., Kovacevic, R. and Stehernik, M. (2007) A Potential Method for Arsenic Removal from Copper Concentrates. Mineral Engineering, 20, 26-33. https://doi.org/10.1016/j.mineng.2006.04.006

[11] Tongamp, W., Takasaki, Y. and Shibamaya, A. (2010) Selective Leaching of Arsenic from Enargite in NaHS-NaOH Media. Hydrometallurgy, 101, 64-68. https://doi.org/10.1016/j.hydromet.2009.11.020

[12] Fornasiero, D., Fullston, D., Li, C. and Ralston, J. (2001) Separation of Enargite and Tennantite from Non-Arsenic Copper Sulfide Minerals by Selective Oxidation or Dissolution. International Journal of Mineral Processing, 61, 109-119. https://doi.org/10.1016/S0301-7516(00)00029-6

[13] Rivera-Vasquez, B.F. and Dixon, D. (2015) Rapid Atmospheric Leaching of Enargite in Acidic Ferric Sulfate Media. Hydrometallurgy, 152, 149-158. https://doi.org/10.1016/j.hydromet.2014.12.012

[14] Gerhardt, N.I., Palant, A.A., Tagirov, V.A. and Tagirov, R.K. (2001) Solvent Extraction of Molybdenum, Tungsten and Vanadium by Diisododecylamine from Leach Liquors. Hydrometallurgy, 60, 1-5. https://doi.org/10.1016/S0304-386X(00)00123-7

[15] Liu, Y.C., Zhong, H. and Cao, Z.F. (2011) Molybdenum Removal from Copper Ore Concentrate by Sodium Hypochlorite Leaching. Mining Science and Technology (China), 21, 61-64. https://doi.org/10.1016/j.mstc.2010.07.002

[16] Cao, Z.F., Zhong, H., Jiang, T., Liu, G.Y. and Wang, S. (2013) Selective Electric-Oxidation Leaching and Separation of Dexing Molybdenite Concentrates. The Chinese Journal of Nonferrous Metals, 23, 2290-2295. (In Chinese)

[17] Romano, P., Blázqueza, M.L., Alguacilb, F.J., Muñoza, J.A., Ballestera, A. and González, F. (2001) Comparative Study on the Selective Chalcopyrite Bioleaching of a Molybdenite Concentrate with Mesophilic and Thermophilic Bacteria. FEMS Microbiology Letters, 196, 71-75. https://doi.org/10.1111/j.1574-6968.2001.tb10543.x

[18] Liu, Y. (1992) Chemical Phase Analysis of Ore and Industrial Products. Metallurgical Industry Press, Beijing, 48-54. (In Chinese)

[19] Fairthorne, G., Fornasiero, D. and Ralston, J. (1997) Effect of Oxidation on the Collectorless Flotation of Chalcopyrite. International Journal of Mineral Processing, 49, 31-48. https://doi.org/10.1016/S0301-7516(96)00039-7

[20] Wagman, D.D., Evans, W.H., Parker, V.B., Schumm, R.H. and Halow, I. (1982) The NBS Tables of Chemical Thermodynamic Properties. Journal of Physical and Chemical Reference Data, 11, Supplement No. 2.

[21] Gow, R., Young, C., Huang, H., Hope, G. and Takasaki, Y. (2014) Spectroelectrochemistry of Enargite I: Reactivity in Alkaline Solutions. Minerals and Metallurgical Processing, 32, 6-3. 
[22] Gow, R., Young, C., Huang, H. and Hope, G. (2014) Spectroelectrochemistry of Enargite II: Reactivity in Acidic Solutions.

[23] Wang, M., Wei, C., Fan, G., Li, M., Deng, Z. and Wang, S. (2015) Selective Extraction of Mo from a Ni-Mo Ore using Pressure Alkaline Leaching. Hydrometallurgy, 153, 6-11. https://doi.org/10.1016/j.hydromet.2015.01.008

[24] Lee, M., Sohn, M. and Lee, M. (2011) Ionic Equilibria and Ion Exchange o Molybdenum (VI) from Strong Acid Solution. Bulletin of the Korean Chemical Society, 32, 3687-3691.

[25] Peters, E. (1976) Direct Leaching of Sulfides: Chemistry and Applications. Metallurgical Transactions B, 7, 505-517. https://doi.org/10.1007/BF02698582

[26] Liu, Z., Xiang, Y., Yin, Z., Wu, X., Jiang, J., Chen, Y. and Xiong, L. (2016) Oxidative Leaching Behavior of Metalliferous Black Shale in Acidic Solution using Persulfate as Oxidant. Transactions of Nonferrous Metals Society of China, 26, 565-574. https://doi.org/10.1016/S1003-6326(16)64145-6

[27] Wang, M., Wei, C., Fan, G., Deng, Z., Wang, S. and Wang, J. (2013) Molybdenum Recovery from Oxygen Pressure Water Leaching Residue of Ni-Mo Ore. Rare Metals, 32, 208-212. https://doi.org/10.1007/s12598-013-0026-0

[28] Liu, Y., Zhang, Y.F., Chen, F.F. and Zhang, Y. (2012) The Alkaline Leaching of Molybdenite Flotation Tailings Associated with Galena. Hydrometallurgy, 129-130, 30-34.

[29] Velásquez, P., Gómez, H., Leinen, D. and Ramos-Barrado, J.R. (1998) Electrochemical Impedance Spectroscopy Analysis of Chalcopyrite $\mathrm{CuFeS}_{2}$ Electrodes. Colloids and Surfaces A: Physicochemical and Engineering Aspects, 140, 177-182. https://doi.org/10.1016/S0927-7757(97)00276-8 